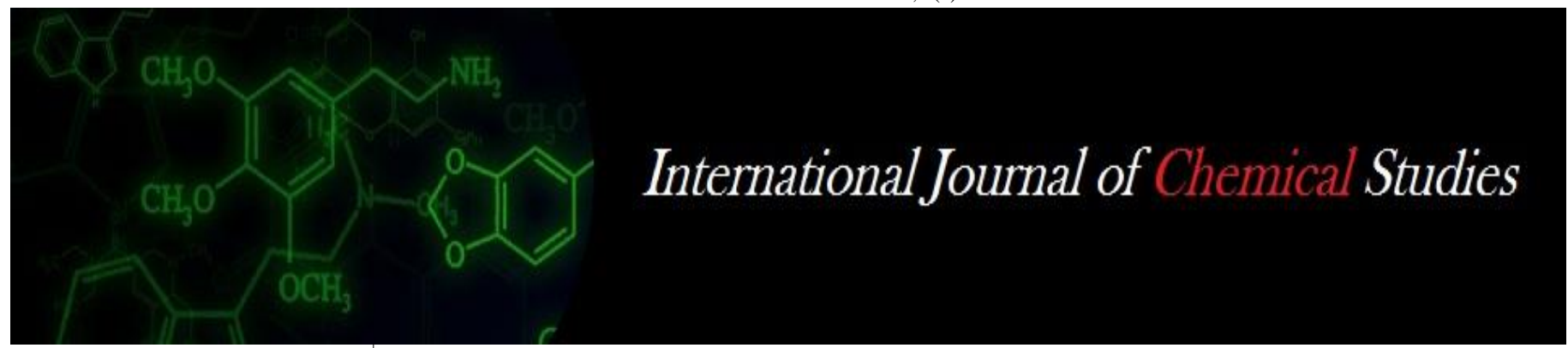

P-ISSN: 2349-8528

E-ISSN: 2321-4902

www.chemijournal.com

IJCS 2020; 8(4): 3858-3861

(C) 2020 IJCS

Received: 01-05-2020

Accepted: 16-06-2020

Sudip Sarkar

Department of Soil Science, Dr.

Rejendra Prasad Central

Agricultural University, Pusa,

Bihar, India

Dipty Kumar Das

Department of Soil Science, Dr.

Rejendra Prasad Central

Agricultural University, Pusa,

Bihar, India

Corresponding Author:

Sudip Sarkar

Department of Soil Science, Dr.

Rejendra Prasad Central

Agricultural University, Pusa,

Bihar, India

\section{Tree biomass and carbon stock assessment in different agroforestry system trees}

\section{Sudip Sarkar and Dipty Kumar Das}

DOI: https://doi.org/10.22271/chemi.2020.v8.i4aw.10251

\begin{abstract}
Climate change and greenhouse effect is considered as a crucial hot topic in present time. By focusing these current issues an investigation taken out on 'Tree biomass and carbon stock assessment in different agroforestry system trees'. The study conducted on three agroforestry systems which includes Kadamb (Anthocephalus cadamba Miq.) based agrisilvicultural system, Simarouba (Simarouba glauca DC) based agrisilvicultural system, Litchi (Litchi chinensis Sonn.) based agrihorticultural system and one open (without trees). Along with the biophysical parameters above ground biomass, below ground biomass, long-lived carbon storage and $\mathrm{CO}_{2}$ mitigation by trees determined. It was noticeable that among the three plantations Simarauba trees were recorded highest Carbon storage and $\mathrm{CO}_{2}$ mitigation ability over tree species. This study supports that these trees can be good pickup for agroforestry development, as they showed good carbon storing and $\mathrm{CO}_{2}$ mitigation capability.
\end{abstract}

Keywords: tree biomass, carbon stock, agroforestry, carbon dioxide mitigation

\section{Introduction}

Trees are considered the largest reservoirs of long-term storage of carbon and in carbon dioxide mitigation of global warming and climate change ${ }^{[1]}$. Rapid increase of population and their attempts towards deforestation mainly to meet local demands for food, fodder, forage and other products, which ultimately challenges existence of forest in our planet. Studies have indicated that forest ecosystems have been depleted indiscriminately in the past. It is also becoming hard to provide food for these increasing population, where cultivated land decreasing due to urbanization and industrialization of cultivable farmlands. An earlier data showed, only $7 \%$ of the total global land covers remain by tropical forests, which play a very significant role in the global carbon mitigation ${ }^{[2]}$. Carbon dioxide $\left(\mathrm{CO}_{2}\right)$ is considered the major greenhouse gas that accelerates current global warming and climate change and there is a need to search for other option to face these challenges. From this aspect agroforestry can be a suitable pick, as it combines agriculture and forestry. Several studies indicated agroforestry can supply all year crop production, at the same time sustain ecosystem, soil and mitigate atmospheric carbon. Trees play important roles in global carbon storage ${ }^{[3]}$, as trees trap the atmospheric $\mathrm{CO}_{2}$ following transformation into plant biomass ${ }^{[4]}$. So it is very important to determine tree biomass to determine carbon stock of that area, for better understanding the ability of tree species to store carbon ${ }^{[5]}$. The current study was conducted with the objective to determine tree biomass and carbon stock in different agroforestry systems located in Samastipur district of Bihar, India.

\section{Materials and methods}

The investigation entitled "Tree biomass and carbon stock assessment in different agroforestry system trees" includes three agroforestry systems as i) Kadamb (Anthocephalus cadamba Miq.) based agrisilvicultural system, ii) Simarouba (Simarouba glauca DC) based agrisilvicultural system, iii) Litchi (Litchi chinensis Sonn.) based agrihorticultural system and one open (without trees) were taken into the study. Kadamb and simarouba based agrisilvicultural system was 13 years old and tree spacing maintained $5 \mathrm{~m} \times 4 \mathrm{~m}$, while in case of litchi spacing maintained $7 \mathrm{~m} \times 7 \mathrm{~m}$. There are two sites is located one at Pusa farm and another at Birauli Farm under Rajendra Prasad Central Agricultural University, Pusa, Bihar. 
Climate is here sub-tropical includes three different seasons rainy (June to September), winter (October-February) and summer (March to May).

Tree heights were measured by using optical Reading Clinometer model no.PM-5/360 PC. Following formulas using for calculating several parameters.

Diameter in breast height $(\mathrm{DBH})=$ Girth/3.14)

Tree girth measured at the height of $1.37 \mathrm{~m}$ from tree base by simple measuring tape.

Tree volume calculated by quarter girth formulae; Volume = $(\mathrm{G} / 4)^{2} \times \mathrm{H}$

Where, $\mathrm{G}=$ Girth of tree at breast height (i.e. at the height of $1.37 \mathrm{~m}$ from tree base), $\mathrm{H}=$ tree height.

Aboveground biomass $(\mathrm{AGB})(\mathrm{q}$ tree -1$)=10 \times$ specific gravity $\times$ timber volume.

Belowground biomass $(\mathrm{BGB})(\mathrm{q}$ tree- 1$)=\mathrm{AGB} \times 15 \%{ }^{[6]}$.

Carbon storage in tree biomass $(q$ tree-1) $=$ Tree biomass $\times$ $45 \%$ [7].

Long-lived carbon storage $(\mathrm{q}$ tree- 1$)=$ Carbon storage in tree stem $\times 42 \%{ }^{[8]}$.

$\mathrm{CO}_{2}$ mitigation by the tree biomass $(\mathrm{q}$ tree- 1$)=$ Carbon storage $\times 3.67$

\section{Results}

\section{Biophysical parameters}

It was found that, among three types of trees, kadamb trees $(9.95 \mathrm{~m})$ were tallest and litchi trees were shostest $(5.15 \mathrm{~m})$

(Fig-1). Fig-2 showed simarouba trees $(0.24 \mathrm{~m})$ had highest diameter at breast height, while kadanb trees $(0.22 \mathrm{~m})$ had lowest diameter at breast height.

The investigation revealed that simarouba trees had higher tree volume over kadamb trees which were higher tree volume over litchi trees (Fig-3). Both Simarouba $\left(0.29 \mathrm{~m}^{3}\right)$ and kadamb $\left(0.28 \mathrm{~m}^{3}\right)$ trees has recorded higher tree volume than litchi trees $\left(0.17 \mathrm{~m}^{3}\right)$.

Above ground biomass and below ground biomass in simarouba trees had higher over kadamb trees whereas kadamb trees had higher over litchi trees (Fig-4). In an average it was found that $87 \%$ of total tree biomass contributed by aboveground biomass and remaining $13 \%$ provided by below ground biomass. Above ground biomass and below ground biomass varied from 7.97 and $1.35 \mathrm{q} \mathrm{tree}^{-1}$ in simarouba trees to 5.91 and $0.92 \mathrm{q} \mathrm{tree}^{-1}$ in litchi trees.

\section{Carbon stock in trees}

In was found that simarouba trees had higher long-lived carbon storage over kadamb trees which were higher longlived carbon storage over litchi trees (Fig-5). Long-lived carbon stock in tree biomass varied from $1.69 \mathrm{q} \mathrm{tree}^{-1}$ in simarouba trees to $1.13 \mathrm{q} \mathrm{tree}^{-1}$ in litchi trees.

Simarouba trees were recorded higher $\mathrm{CO}_{2}$ mitigation over kadamb trees which were higher $\mathrm{CO}_{2}$ mitigation over litchi trees (Fig-6). It was also found that $\mathrm{CO}_{2}$ mitigation by trees varied from $15.13 \mathrm{q}_{\text {tree }}^{-1}$ by simarouba trees to $12.11 \mathrm{q} \mathrm{tree}^{-1}$ by litchi trees.

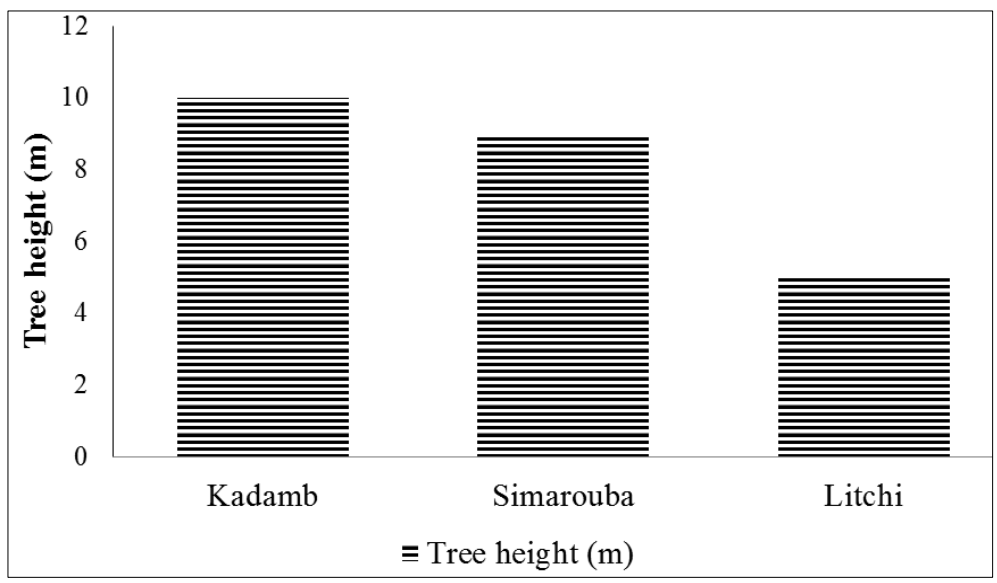

Fig 1: Heights of different trees under agroforestry systems

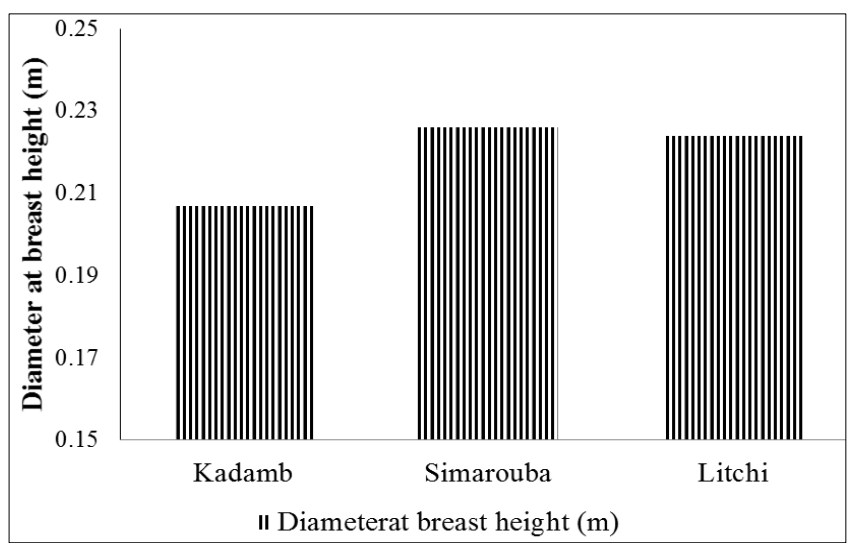

Fig 2: Diameter at breast heights of different trees under agroforestry systems

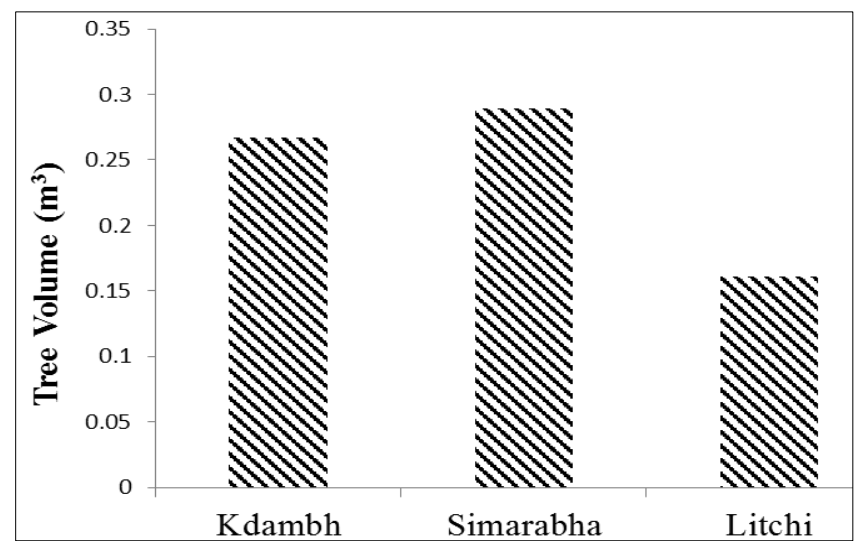

Fig 3: Tree volumes of different tree species 


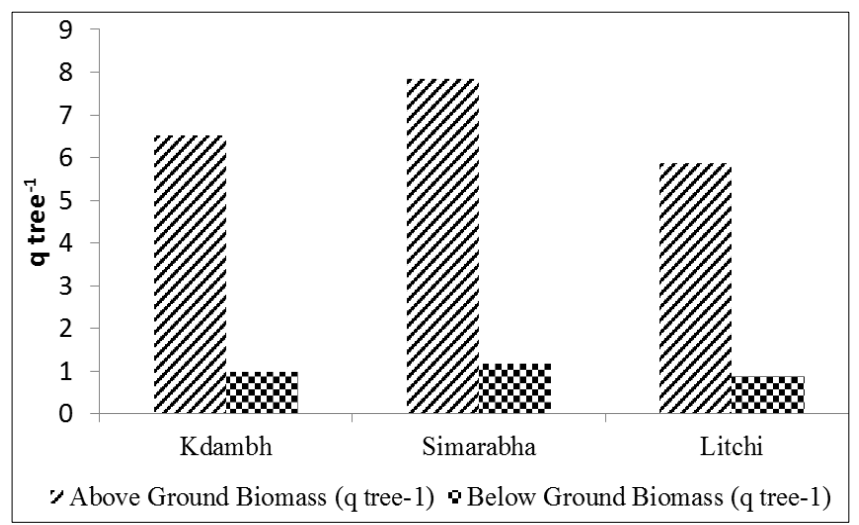

Fig 4: Above ground biomass and below ground biomass presence in different tree species

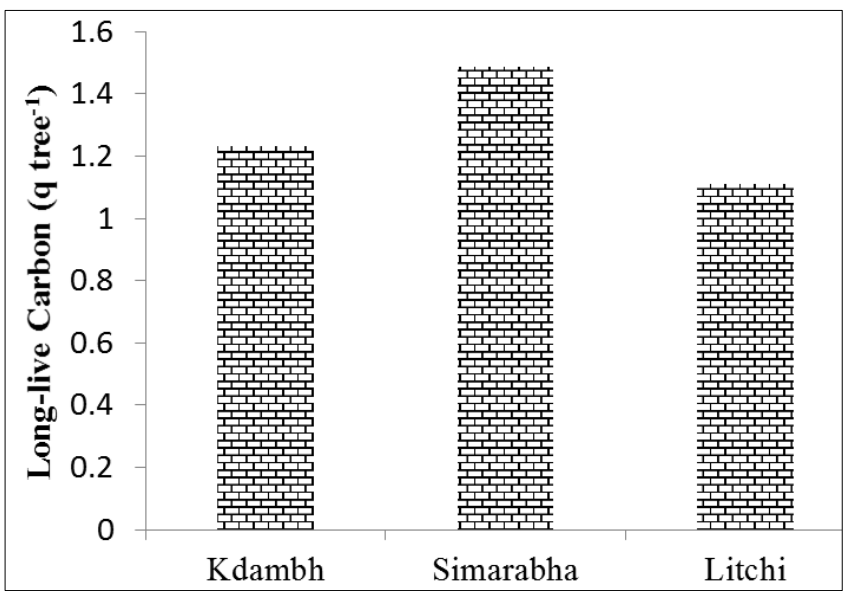

Fig 5: Long lived carbon presence in different tree species

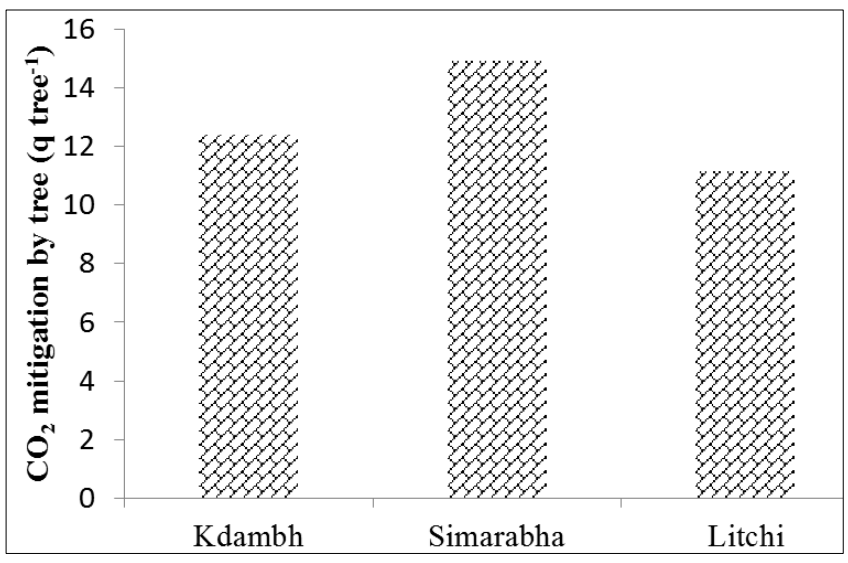

Fig 6: $\mathrm{CO}_{2}$ mitigation by different tree species

\section{Discussion \\ Biophysical parameters}

It was found that, among three types of trees, kadamb trees were tallest and litchi trees were shortest, which may be due to pruning of litchi trees for easy harvesting of fruits, on the other hand kadamb and simarouba plantation develops with maintaining close spacing and no pruning done. Simarouba trees had highest diameter at breast height, while kadanb trees had lowest diameter at breast height. Close spacing trees has higher heights and larger diameter at breast height, previously reported by Kar et al. (2019) [9]. The investigation revealed that simarouba trees had higher tree volume over kadamb trees which were higher tree volume over litchi trees. Both Simarouba and kadamb trees has significantly higher tree volume than litchi trees. Seasonal trimming may reduce volume of litchi trees.
All above ground tree parts including stem, branch, bark, seed, foliage etc. called as above ground biomass (AGB), while below ground biomass (BGB) includes plant roots ${ }^{[10]}$. AGB and BGB in simarouba trees had higher over kadamb trees whereas kadamb trees had higher over litchi trees. AGB and BGB variations among the tree species mentioned in several past works ${ }^{[11,12,13]}$. In an average it was found that majority of total tree biomass contributed by AGB and remaining provided by BGB. Similarly, Sohrabi et al., (2016) ${ }^{[11]}$, Gebrewahid et al. (2018) ${ }^{[12]}$ and Yadav et al., (2019) ${ }^{[13]}$ also found contribution of AGB in total tree biomass was more than BGB.

\section{Carbon stock in trees}

In was found that simarouba trees had higher long-lived carbon storage over kadamb trees which were higher longlived carbon storage over litchi tree. There is a significant advantage of long-term carbon storage through agroforestry development compared to crop production ${ }^{[14]}$. Long-lived trees contribute bulk of carbon storage in tropical rainforests, they also known as long-lived pioneers and play major role to fight clime change ${ }^{[15]}$.

Agroforestry has been got well recognition as having huge potentiality for carbon sequestration of all land type land managements ${ }^{[16]}$. Simarouba trees were recorded higher $\mathrm{CO}_{2}$ mitigation over kadamb trees, those were higher $\mathrm{CO}_{2}$ mitigation over litchi trees. Contributions of tree species in $\mathrm{CO}_{2}$ mitigation was well mentioned in the past works of Grote (2009) ${ }^{[17]}$, Costa et al. (2018) ${ }^{[18]}$ and Naik et al. (2018) ${ }^{[19]}$.

\section{Conclusion}

There were variations of all recorded biophysical and carbon stock parameters among three tree species, as it natural that every tree species had different growth patterns. It is also noticeable that all tree species has good ability to store longtermed carbon in their long-lived bodies. Among the tree species simarouba trees were found to contain largest carbon stock and has highest capability in $\mathrm{CO}_{2}$ mitigation. So, finally it can conclude that with current climate change concern these tree species can be good options for agroforestry development, as they stock huge carbon for long-term and mitigate $\mathrm{CO}_{2}$.

\section{References}

1. Arasa-Gisbert R, Vayreda J, Roman Cuesta RM, Villela SA, Mayorga R, Retana J. Forestdiversity plays a key role in determining the stand carbon stocks of Mexican forests. Forest Ecology and Management. 2018; 415:160171.

2. Nascimento HE, Laurance WF. Total aboveground biomass in central Amazonian rainforests: A landscapescale study. Forest Ecology and Management. 2002; 168(1-3):311-321.

3. Shirima DD, Totland $\varnothing$, Munishi PK, Moe SR. Relationships between tree species richness, evenness and aboveground carbon storage in montane forests and miombo woodlands of Tanzania. Basic and Applied Ecology. 2015; 16(3):239-249.

4. Ravindranath NH, Somashekhar BS, Gadgil M. Carbon flow in Indian forests. Climatic Change. 1997; 35(3):297320.

5. Malhi YA, Baldocchi DD, Jarvis PG. The carbon balance of tropical, temperate and boreal forests. Plant, Cell \& Environment. 1999; 22(6):715-740. 
6. Marak T, Khare N. Carbon sequestration potential of selected tree species in the campus of Shuats, 2017. IJSRD/Vol.5/Issue 06/2017/016.

7. Magnussen S, Reed D. Modeling for estimation and monitoring, 2004. Faoiufro.

8. Wang $\mathrm{X}$, Feng $\mathrm{Z}$. Atmospheric carbon sequestration through agroforestry in China. Energy. 1995; 20:117-121.

9. Kar S, Pant KS, Chandel A, Roshanzada SR. Trend of soil parameters under different spacings of Grewia based agroforestry system in the mid hill zones of Himachal Pradesh. International Journal of Chemical Studies. 2019; 7(1):1904-1907.

10. IPCC. IPCC (Intergovernmental Panel on Climate Change) guidelines for greenhouse gasInventories. 2006; Vol. 4, Agriculture, forestry and other land use, 2006.

11. Sohrabi H, Bakhitiarvand-Bhakhtiari S, Ahmadi K. Above and below-ground biomass and carbon stocks of different tree plantations in central Iran. Journal of Arid Land. 2016; 8(1):138-145.

12. Gebrewahid Y, Gebre-Egziabhier TB, Teka K, Gebrewahid EB. Carbon stock potential of scattered trees on farmland along an altitudinal gradient in Tigray, Northern Ethiopia. Ecological Processes. 2018; 7:40.

13. Yadav RP, Gupta B, Bhutia PL, Bisht JK, Pattanayak A, Meena VS et al. Biomass and carbon budgeting of sustainable agroforestry systems as ecosystem service in Indian Himalayas. International Journal of Sustainable Development \& World Ecology. 2019; 26(5):460-470.

14. Kaul M, Mohren GMJ, Dadhwal VK. Carbon storage and sequestration potential of selected tree species in India. Mitig Adapt Strateg Glob Change. 2010; 15:489-510.

15. Rüger $\mathrm{N}$ et al. Demographic trade-offs predict tropical forest dynamics. Science, Apr 10th, 2020. DOI: $10.1126 /$ science.aaz4797

16. IPCC. Land use, land-use change, and forestry. Cambridge University Press, Cambridge, UK, 375 A special report of the IPCC, 2000.

17. Gorte WR. Carbon Sequestration in Forests, Congressional Research Service, Natural Resources Policy, Report for Congress, 2009, 7-5700 www.crs.gov RL31432.

18. Costa END, Souza MFL, Marrocos PCL, Lobão D, Silva DML. Soil organic matter and $\mathrm{CO}_{2}$ fluxes in small tropical watersheds under forest and cacao agroforestry. July 16, 2018. https://doi.org/10.1371/journal.pone.0200550

19. Naik SK, Sarkar PK, Das B, Singh K, Bhatt BP. Predict model for dry biomass and carbon stock estimation in Litchi Chinensis under hot and dry sub-humid climate. Archives of Agronomy and Soil Science, 2018, 64(10). 